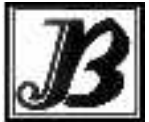

J. bio-sci. 21: 61- 68, 2013

ISSN 1023-8654

http://www.banglajol.info/index.php/JBS/index

\title{
SUSCEPTIBILITY OF FOODBORNE PATHOGENS AND SPOILAGE MICROORGANISMS TO SEED EXTRACTS OF CITRULLUS VULGARIS AND CITRUS RETICULATA
}

\author{
Omogbai B $\mathrm{A}^{1^{*}}$ and Ahonsi G $\mathrm{M}$ \\ ${ }_{1}^{1}$ Department of Microbiology, Faculty of Life Sciences, University of Benin, Benin City, Nigeria
}

\begin{abstract}
Context: The importance of herbs in the management of food borne pathogens and spoilage organisms is of current interest since many plant components are bioactive and relatively safe when taken. Plant parts of Citrus reticulata and Citrullus vulgaris are used in herbal therapy in some parts of the world.

Objective: The objective of this study was to evaluate the susceptibility of foodborne pathogens and spoilage microorganisms to seed extracts of Citrus reticulata and Citrullus vulgaris.

Materials and Methods: The antimicrobial effect of ethanol and hot water extracts of $C$ reticulata and $C$ vulgaris seeds were studied using agar well diffusion technique. Minimum inhibitory concentration was performed using the modified tube dilution technique. The extracts were assayed on pure cultures of Bacillus subtilis, Staphylococcus aureus, Salmonella typhi, Escherichia coli, Saccharomyces cerevisiae and Aspergillus flavus.

Results: Extracts tested at various concentrations produced in-vitro antimicrobial activities against foodborne isolates of $B$ subtilis, $S$ aureus, $S$ typhi, $E$ coli, $S$ cerevisiae and $A$ flavus. The highest zone of inhibition was obtained from ethanol extract at $4000 \mu \mathrm{g} / \mathrm{ml}$ against $B$ subtilis with diameter of $25 \mathrm{~mm}$ for $C$ reticulata. The lowest zone of inhibition of $10 \mathrm{~mm}$ was obtained for $E$ coli at $4000 \mathrm{~g} / \mathrm{ml}$ for the hot water extract of $C$ vulgaris. The minimum inhibitory concentration (MIC) of the water extract of $C$ reticulata and $C$ vulgaris seeds ranged between $125-2000 \mu \mathrm{g} / \mathrm{ml}$. The MIC of the ethanol extract of the seeds of both plants was in the range $62.5-1000 \mu \mathrm{g} / \mathrm{ml}$.Comparatively, the ethanol extract of the seeds were more potent than the hot aqueous extract. The percent killing of the ethanol extract at $2000 \mu \mathrm{g} / \mathrm{ml}$ was higher for $C$ reticulata (45.6-100\%) compared to that of $C$ vulgaris (35.6-87.5).

Conclusion: The results show that the ethanol extracts of Citrus reticulata and Citrullus vulgaris have potentential application for shelf life extension and as a pharmaceutical preparation.
\end{abstract}

Key words: Antimicrobial, ethanol, extract, Seeds, Citrus reticulata, Citrullus vulgaris.

Introduction

Even though pharmacological industries have produced a number of new antibiotics in the last decades, resistance to these drugs by Microorganisms has increased. In general, bacteria have genetic ability to transmit and acquire resistance to drugs, which are utilized as therapeutic agents (Romero et al. 2005). The importance of herbs in the management of food-borne pathogen cannot be overemphasized. It is clear that the plant kingdom harbors an inexhaustible source of active ingredients invaluable in the management of many untreatable diseases (Afolayan 2003). However, these complementary components give the plant as a whole a safety and efficiency much superior to that of its isolated and pure active component (Shariff 2001). Herbal medicines have made large contributions to human health- illness and provide a good source of antiinfective agents; emetine, quinine, and berberine remain highly effective instruments in the fight against infections (Basile et al. 2000). Although hundreds of plant species have been tested for antimicrobial properties, the vast majority of them have not been adequately evaluated (Balandrin et al. 1985). Plants and plant products are a source of natural alternatives to improve the shelf life and the safety of food. Recently, the interest in the application of the seed extract to control plant and post-harvest pathogen has increased

* Corresponding author E-mail: barryomogbai@yahoo.com 
and their potential role in food preservation is been exploited. Numerous naturally occurring antimicrobials are present in plant tissues and many studies have evaluated the antimicrobial activities of several plant extracts (Agatemor 2009, Omogbai and Eze 2011).

The use of plant extracts and phytochemicals can be of great significance in therapeutic treatment (Ikram and Inamul, 1984). Many plants have been used because of their antimicrobial traits, which are due to compounds synthesized as secondary metabolism of the plant. These products include the phenolic compounds which are part of the essential oils as well as tannin.

Tangerine oil obtained from the seed of Citrus reticulata, is traditionally used as an antiseptic, antispasmodic, stomachic, sedative, diuretic and to improve circulation (Odugbemi 2006). Watermelon (Citrullus vulgaris) is a popular fruit consumed all over the world. Besides its juicy texture, watermelon is rich in useful antioxidant, lycopene which has been demonstrated to inhibit growth of cancer cells (Hall 2004). It is a rich source of citrulline, an amino acid that can be metabolized to arginine, an essential amino acid for humans used in the synthesis of nitric oxide and plays an essential role in cardiovascular and immune function (Collins et al. 2007).

Tangerine and watermelon seed possesses therapeutic activities against a wide range of ailment including inflammatory disorders, arthritis, and gout (Marzouk et al. 2009). Microbial contamination reduces the shelf life of foods and increases the risk of food-borne illness. An application of antimicrobial preservative treatment in food packaging is gaining interest from researchers due to its potential to provide quality, safety benefits and to extend the shelf life of the food (Devlieghere et al. 2000, Church and Persons 2007).

The objective of this study is to screen medicinal plants like Citrus reticulata and Citrullus vulgaris for promising biological activity against food-borne spoilage and pathogenic organisms such as Bacillus subtilis, $S$ aureus, $S$ typhi, $E$ coli, $S$. cerevisiae and $A$ flavus.

\section{Materials and methods}

Source of materials: Tangerine fruits (Citrus reticulata) and watermelon fruits (Citrullus vulgaris) were purchased from Uselu market, Benin City, Edo State, Nigeria. The seeds were removed and identified in the Department of Plant Biology and Biotechnology, University of Benin, Benin City.

\section{Source of microbial cultures}

Microbial culture employed in this experiment were stock cultures of Gram-positive (Bacillus subtilis and Staphylococcus aureus), Gram-negative bacteria (Escherichia coli and Salmonella typhi) and fungi (Aspergillus flavus and Saccharomyces cerevisiae). Bacterial cultures were obtained from the Department of Medical Microbiology, University of Benin Teaching Hospital, Benin City. Fungi were isolated from deteriorating pineapple fruit. These cultures were identified using the methods of Collins and Lyne (2004), Barnett et al. (2000) and Barnett and Hunter (1998). The bacteria and fungi were re-isolated in nutrient agar and potato dextrose agar respectively. The bacteria were maintained on nutrient agar slants at $37^{\circ} \mathrm{C}$ and fungi on saboraud dextrose agar (SDA) at $28^{\circ} \mathrm{C}$ until used.

\section{Preparation of extracts of the seeds of Citrus reticulata and Citrullus vulgaris}

Fresh seeds of two plants Citrus reticulata (tangerine) and Citrullus vulgaris (watermelon) were obtained and washed individually with sterile distilled water and oven-dried for one hour at $60^{\circ} \mathrm{C} .300 \mathrm{~g}$ of each of respective dry seeds (tangerine and watermelon) were blended into fine powder. A quantity of $0.4 \mathrm{~g}$ fine grinded powder was dissolved in $10 \mathrm{ml}$ of solvent: ethanol, cold or hot water in a test tube and stirred properly to give extract with a concentration of $4000 \mu \mathrm{g} / \mathrm{ml}$ which served as stock. This stock was diluted following the method of Nair and Chanda (2007). $2 \mathrm{ml}$ of distilled water was poured into seven test tubes. $2 \mathrm{ml}$ of extract 
from the stock was transferred into a test tube containing $2 \mathrm{ml}$ of distilled water to give a 1 in 2 dilution with concentration of $2000 \mu \mathrm{g} / \mathrm{ml}$ of extract. From this test tube $2 \mathrm{ml}$ was removed to the next tube to give a dilution of 1 in 4 with a concentration of $1000 \mu \mathrm{g} / \mathrm{ml}$ of extract. This process was repeated up to the seventh test tube to obtain various concentrations of extract. Then $2 \mathrm{ml}$ was removed from the last test tube and discarded (Nair and Chanda 2007).

\section{Antimicrobial susceptibility assay}

The method of Denyer et al. (2004) was employed as follows. Bacterial and fungal isolates were spread unto solidified nutrient and saboraud dextrose agar respectively. Holes $(4 \mathrm{~mm})$ were then made in the agar using a sterile puncher and the bottom of each hole was sealed with molten agar. Aliquots of $0.5 \mathrm{ml}$ of extract of different concentrations for each of the two plants was transferred into several holes made on agar plates and labeled accordingly for each of the three (ethanol, cold or hot water) extracts respectively. The plates were left on the bench for 30 minutes to allow diffusion of extract and later incubated for $72 \mathrm{hrs}$ at $28 \pm 20$ for fungal isolates and $24 \mathrm{hrs}$ at $37 \mathrm{C}$ for bacterial isolates to observe the zones of growth inhibition produced by the extract. Zones of inhibition were determined using a pair of callipers.

\section{Determination of minimum inhibitory concentration (mic)}

This was performed with modifications using the tube dilution method described by Cheesebrough (2000); Omogbai and Eze (2011). A double fold serial dilution of the extracts was made using Mueller Hinton broth (MHB) to obtain 800, 400, 200, 100, 50, 25 and $12.5 \mu \mathrm{g} / \mathrm{ml}$. Equal volume of extract and MHB (2ml) was dispensed into sterile test-tubes. $0.1 \mathrm{ml}$ of standardized inoculum $(1.4 \times 107 \mathrm{cfu} / \mathrm{ml}$ was added to each of the test-tubes followed by incubated at $37^{\circ} \mathrm{C}$ for $24 \mathrm{~h}$ for bacteria and $28 \pm 20^{\circ} \mathrm{C}$ for $72 \mathrm{~h}$ for fungi. The organism control tube contained only broth and inoculum without extract.

\section{Determination of minimum microbicidal concentration}

This was performed as an adjunct to the MIC test and used to determine the minimal concentration of the extract that is lethal to the target organism's in-vitro. Sterile Muller Hinton agar plates were inoculated with samples from each of the test-tubes that showed no visible growth from the MIC test. The plates were then incubated at $37^{\circ} \mathrm{C}$ for $24 \mathrm{~h}$ for bacteria and $28 \pm 2{ }^{\circ} \mathrm{C}$ for $72 \mathrm{~h}$ for fungi. The lowest concentration of extract that showed no growth was taken as the minimum microbicidal concentration (Espinell-Ingroff et al. 2002, Omogbai 2012).

\section{Assay for percent microbicdal activity}

The assay for microbicidal activity was carried out by colony count on agar plates as described by Omogbai, 2012. To a flask was added $1.0 \mathrm{ml}$ of test strain (106CFU), $1.0 \mathrm{ml}$ of the sterile (membrane filter, $0.22 \mu \mathrm{m}$ pore size) extract solution and $3.0 \mathrm{ml}$ of $0.05 \mathrm{M}$ acetate buffer $(\mathrm{pH} 6.0)$. $1.0 \mathrm{ml}$ of acetate buffer was used as control. The reaction flask was incubated with shaking at $370 \mathrm{C}$ for $1 \mathrm{~h}$ for test bacteria and $28 \pm 20 \mathrm{C}$ for $3 \mathrm{~h}$ for test fungi, respectively. $1.0 \mathrm{ml}$ of the reaction mixture was added to the agar medium on the petri dish, and then incubated at $37^{\circ} \mathrm{C}$ for $24 \mathrm{~h}$ for bacteria and $28 \pm 2{ }^{\circ} \mathrm{C}$ for $72 \mathrm{~h}$ for test fungi respectively. After incubation, the colonies were counted to indicate microbicidal activity.

Microbicidal (Bactercidal or fungicidal) activity (\%) $=\mathrm{C}-\mathrm{T} \times 100 \mathrm{C}$

Where $\mathrm{C}=$ numbers of colonies counted on control plate

$\mathrm{T}=$ numbers of colonies obtained from each tested sample solution

\section{Results}

Seed extracts of Citrus reticulata and Citrullus vulgaris exhibited bactericidal and fungicidal activity against all tested microorganisms. $B$ subtilis showed the highest sensitivity to ethanol extract of both seeds of $C$ 
reticulata and C vulgaris with zones of inhibition of $22.0 \mathrm{~mm}$ and $25.0 \mathrm{~mm}$ at $4000 \mu \mathrm{g} / \mathrm{ml}$ respectively. Escherichia coli and $S$ typhi showed the least antibacterial sensitivity to ethanol seed extract of $C$ reticulata and $C$ vulgaris with zones of inhibition ranging from $13.0 \mathrm{~mm}$ to $18.0 \mathrm{~mm}$ at $4000 \mu \mathrm{g} / \mathrm{ml}$.

Saccharomyces cerevisiae showed the highest susceptibility to ethanol extract of $C$ reticulata and $C$ vulgaris with zones of inhibition of $25.0 \mathrm{~mm}$ and $30.0 \mathrm{~mm}$ at $4000 \mu \mathrm{g} / \mathrm{ml}$ respectively, compared to Aspergillus flavus with zones of inhibition of $14.0 \mathrm{~mm}$ and $18.0 \mathrm{~mm}$ at $4000 \mu \mathrm{g} / \mathrm{ml}$ respectively. Among the bacteria, MIC ranged from 62.5 to $2000 \mu \mathrm{g} / \mathrm{ml}$ for both the hot water and ethanol extracts of $C$ vulgaris and $C$ reticulata (Table 3 ).

Table 3. Minimum inhibitory concentration of seed extracts.

\begin{tabular}{|c|c|c|c|c|}
\hline \multirow[t]{3}{*}{ Test isolates } & \multicolumn{4}{|c|}{ MIC $(\mu \mathrm{g} / \mathrm{ml})$} \\
\hline & \multicolumn{2}{|c|}{ Citrullus vulgaris } & \multicolumn{2}{|c|}{ Citrus reticulata } \\
\hline & Ethanol & Hot water & Ethanol & Hot water \\
\hline Bacillus subtilis & 250 & 500 & 125 & 125 \\
\hline Escherichia coli & 1000 & 2000 & 500 & 1000 \\
\hline Salmonella typhi & 1000 & 2000 & 1000 & 2000 \\
\hline Staphylococcus aureus & 62.5 & 500 & 62.5 & 500 \\
\hline Aspergillus flavus & 500 & 1000 & 250 & 2000 \\
\hline Saccharomyces cerevisiae & 125 & 1000 & 62.5 & 500 \\
\hline
\end{tabular}

Table 4. Minimum microbicidal concentration $(\mathrm{mmc})$ of seed extracts.

\begin{tabular}{lcccc}
\hline Test isolates & \multicolumn{2}{c}{ MMC $(\mu \mathrm{g} / \mathrm{ml})$} & \multicolumn{2}{c}{ Citrus reticulata } \\
\hline & Ethanol & Hot water & Ethanol & Hot water \\
\hline Bacillus subtilis & 500 & 1000 & 125 & 1000 \\
Escherichia coli & 4000 & 4000 & 1000 & 2000 \\
Salmonella typhi & 2000 & 4000 & 2000 & 4000 \\
Staphylococcus aureus & 250 & 1000 & 62.5 & 2000 \\
Aspergillus flavus & 2000 & 4000 & 500 & 4000 \\
Saccharomyces cerevisiae & 1000 & 4000 & 250 & 2000 \\
\hline
\end{tabular}

The ethanolic extracts of the seeds showed the highest activity against $S$ aureus followed by $B$ subtilis and least on $E$ coli and $S$ typhi. With the fungi, Saccharomyces cerevisiae was more susceptible compared to $A$ flavus (Table 3).The minimum microbicidal concentration of the seed extracts showed higher values compared to the MICs. (Table 4). The antimicrobial effectiveness of the ethanol extracts at $2000 \mu \mathrm{g} / \mathrm{ml}$ showed that Citrus reticulata was more effective with a percent killing range of 45.6 to $100 \%$. On the other hand with Citrullus vulgaris the percent killing rate of the tested organisms were 35.6 to $85.7 \%$. In comparison the microorganisms were more susceptible to the ethanol extracts compared to the hot water extracts (Table 5). 


\section{Discussion}

The results of this study indicates that ethanol extracts of the seeds of Citrus reticulata and Citrullus vulgaris exhibited antimicrobial potency against the test organisms like $B$ subtilis, $S$ aureus, $E$ coli, $S$ typhi, A flavus and $S$ cerevisiae. Generally, the ethanolic extract showed greater antimicrobial activity compared to its corresponding hot aqueous extract. The antimicrobial potency observed in these seed extracts justifies their use by herbal physians and the use of alcohol as extractants in the preparation of crude drugs from medicinal plants. When alcohol is used for extraction, the bioactive substances that are less soluble in water are dissolved by the solvent (Jigna and Sumitra, 2006). The ethanolic extract of $C$ reticulata exhibited the highest (100\%) antimicrobial effect against $B$ subtilis, $S$ aureus and $S$ cerevisiae. The inhibitory effect on both gram-positive and gram-negative bacteria makes the extract broad spectrum (Table 1). The zones of inhibition which increased as the concentrations of the extracts increased shows the antimicrobial activity to be concentration dependent (Tables 1 and 2).

Table 1. Susceptibility profile of Citrus reticulata and Citrullus vulgaris seed extract against food-borne pathogens.

\begin{tabular}{|c|c|c|c|c|c|c|c|c|c|c|c|c|c|c|c|c|}
\hline \multicolumn{17}{|c|}{ Zone of inhibition (mm) } \\
\hline \multicolumn{8}{|c|}{ Citrullus vulgaris } & \multicolumn{9}{|c|}{ Citrus reticulata } \\
\hline \multirow{2}{*}{$\begin{array}{l}\text { Concentration } \\
(\mu \mathrm{g} / \mathrm{ml})\end{array}$} & \multicolumn{3}{|c|}{ Hot water extract } & \multicolumn{4}{|c|}{ Ethanol extract } & \multicolumn{4}{|c|}{ Hot water extract } & \multicolumn{4}{|c|}{ Ethanol extract } & \\
\hline & BS & $\mathrm{EC}$ & SA & ST & BS & EC & SA & ST & BS & $\mathrm{EC}$ & SA & ST & BS & $\mathrm{EC}$ & SA & ST \\
\hline 4000 & 17 & 10 & 10 & 13 & 22 & 13 & 20 & 15 & 22 & 14 & 24 & 14 & 25 & 18 & 28 & 17 \\
\hline 2000 & 16 & 9 & 9 & 11 & 17 & 10 & 18 & 13 & 19 & 12 & 16 & - & 22 & 14 & 24 & 15 \\
\hline 1000 & 12 & - & 7 & - & 15 & 6 & 16 & 8 & 15 & 10 & 12 & - & 18 & 10 & 22 & 12 \\
\hline 500 & 10 & - & 6 & - & 14 & - & 14 & - & 10 & - & 9 & - & 14 & 6 & 16 & - \\
\hline 250 & - & - & - & - & 11 & - & 13 & - & 8 & - & - & - & 10 & - & 12 & - \\
\hline 125 & - & - & - & - & - & - & 11 & - & 6 & - & - & - & 8 & - & 7 & - \\
\hline 62.5 & - & - & - & - & - & - & 8 & - & - & - & - & - & - & - & - & - \\
\hline 31.25 & - & - & - & - & - & - & - & - & - & - & - & - & - & - & - & - \\
\hline
\end{tabular}

BS= Bacillus subtilis $\quad \mathrm{EC}=$ Escherichia coli $\mathrm{ST}=$ Salmonella typhi $\mathrm{SA}=$ Staphylococcus aureus - = No zone of inhibition. 
Table 2. Susceptibility profile of citrus reticulata and citrullus vulgaris seed extract against food spoilage fungi

\begin{tabular}{|c|c|c|c|c|c|c|c|c|}
\hline \multicolumn{9}{|c|}{ Zone of inhibition (mm) } \\
\hline & \multicolumn{4}{|c|}{ Citrullus vulgaris } & \multicolumn{4}{|c|}{ Citrus reticulata } \\
\hline \multirow[t]{2}{*}{ Concentration (, g/ml) } & \multicolumn{2}{|c|}{ Hot water extract } & \multicolumn{2}{|c|}{ Ethanol extract } & \multicolumn{2}{|c|}{ Hot water extract } & \multicolumn{2}{|c|}{ Ethanol extract } \\
\hline & AF & SC & AF & Sc & $\mathrm{AF}$ & sc & AF & SC \\
\hline 4000 & 10 & 20 & 14 & 25 & 12 & 25 & 18 & 30 \\
\hline 2000 & 10 & 18 & 12 & 23 & 10 & 22 & 10 & 26 \\
\hline 1000 & 08 & 15 & 10 & 19 & 07 & 15 & 09 & 22 \\
\hline 500 & 00 & 00 & 08 & 15 & 00 & 11 & 08 & 18 \\
\hline 250 & 00 & 00 & 00 & 13 & 00 & 00 & 06 & 15 \\
\hline 125 & 00 & 00 & 00 & 10 & 00 & 00 & 00 & 12 \\
\hline 62.5 & 00 & 00 & 00 & 00 & 00 & 00 & 00 & 09 \\
\hline 31.25 & 00 & 00 & 00 & 00 & 00 & 00 & 00 & 00 \\
\hline
\end{tabular}

$\mathrm{AF}=$ Aspergillus flavus $\quad \mathrm{PC}=$ Saccharomyces cerevisiae $\quad 00=$ No zone of inhibition

The cold extracts of the seeds did not exert antimicrobial effect due to the failure of the bioactive ingredients to dissolve in it. The fact that ethanol extract did not exert $100 \%$ killing of the pathogens shows that it is both bacteriostatic and bactericidal (Table 5).

Table 5. Percent microbicidal activity of ethanol seed extracts of Citrus reticulata and Citrullus vulgaris at $2000 \mu \mathrm{g} / \mathrm{ml}$.

\begin{tabular}{lll}
\hline Test Isolates & Percent Microbicidal Activity \\
\hline & Citrus reticulata & Citrullus vulgaris \\
\hline Bacillus subtilis & 100 & 80.0 \\
Escherichia coli & 97.5 & 82.1 \\
Salmonella typhi & 45.6 & 35.6 \\
Staphylococcus aureus & 100 & 85.7 \\
Aspergillus flavus & 95.8 & 80.5 \\
Saccharomyces cerevisiae & 100 & 76.8 \\
\hline
\end{tabular}

The results obtained from all the ethanol extracts showed the susceptibility of the extract on all food-borne pathogen tested. This probably indicates that there are bioactive ingredients such as alkaloids, flavonoids, tannins and polyphenols that are inhibitory to the growth of these common pathogens (Irobi and Daranola 1994). Furthermore, ethanol extract produced the highest zones of inhibition compared to water extract. This finding agrees with the report of Amadioha (2000) who stated that many factors influence the active principles present in plants which included: the age of plants, extracting solvent, method of extraction and time of harvesting plant materials. The results obtained from this investigation clearly indicate that the antibacterial and antifungal activity vary with the species of the plants and plant material used as seen in the 
two medicinal plant which could be of considerable interest to the development of new drugs. Furthermore, the drugs made from the extracts can be of potential help to treat ailments such as gastrointestinal disorder and food-borne illness in which the tested pathogens such as E.coli, Salmonella typhi and Staphylococcus aureus may be implicated.

\section{Conclusion}

Plant extracts have great potential as antimicrobial compounds against microorganisms. Thus, they can be used as preservatives and in the treatment of infections caused by microbes. The result of the present study suggest that seed extracts of Citrus reticulata and Cirullus vulgaris possess compounds containing antimicrobial properties that can be useful to control food-borne pathogens. The antimicrobial characteristics of the ethanol extract of the seed of these plants would be useful in the shelf life extension of food and foodproducts. Finally, the successful development of chemotherapeutic agent from $C$ reticulata (Tangerine) and $C$ vulgaris (Watermelon) respectively will contribute to the development of antimicrobial drugs.

\section{References}

Afolayan AJ. 2003. Extracts from the shoots of Citrus aurantifola inhibit the growth of bacteria and fungi. Pharm Biol 41, 22-25. http://dx.doi.org/10.1076/phbi.41.1.22.14692

Agatemor C. 2009. Antimicrobial activity of aqueous and ethanol extracts of nine Nigerian spices against four foodborne bacteria. Ari J Med Sci 255, 221-224.

Aibinu I, Mee BJ. 2003. Extended- Spectrum Beta- Lactamases in isolated of Klebsiella Spp. and Escherichia coli from Lagos Niiger J Health Biomed Sci 2(2), 53-60.

Amadioha AC. 2000. Fungicidal activity of some plant extracts against Rhizoctomia solani in cowpea. Arch pathology of Lanzo 20,1-9.

Balandrin MF, Kjocke AJ, Wurtele E. 1985. Natural plant chemicals: sources of industrial and mechanical materials Science 228: 1154-1160. http://dx.doi.org/10.1126/science.3890182

Barnett JA, Payne R.W, Yarrow D. 2000. Yeasts: Characterisation and Identification 3rd ed. Cambridge , England, 978pp.

Barnett HL, Hunter BB. 1998. Illustrated Genera of Imperfect Fungi. 4th ed. Burgess publishing company, Minneapolis, USA 218pp.

Basile A, Sorbo S, Giordano S, Ricciardi L., Ferrara S, Montesano D, Castaldo CR., Vuotto M.L., Ferrara L. 2000..Antibacterial and allelopathic activity of extract from Castanea sativa leaves. Fitoterapia 71: 110-116. http://dx.doi.org/10.1016/S0367-326X(00)00185-4

Cheesbrough M. 2000. District Laboratory Practice in Tropical Countries. Part II Cambridge University Press. UK. 260 p.

Church I, Persons A. 2007. Antimicrobial film for food applications: A quantitative analysis of their effectiveness. Packaging Technol Sci 20, 231-273. http://dx.doi.org/10.1002/pts.774

Collin CH, Patricia M, Lyne, Grarge TM Falkinham JO. 2004. Collins and Lyne's Microbiological Methods. $8^{\text {th }}$ ed. Arnold publishers London U.K. . pp. 215-456

Collins G. Wu JK, PerkinsVeazie P, Spears K, Claypool PL, Baker RA., Clevidence BA.2007. Watermelon consumption increases plasma arginine concentrations in adults. Nutri 23, 261-266. http://dx.doi.org/10.1016/j.nut.2007.01.005

Denyer SP, Hadger NA, Girman SP. 2004. Hugo and Russell's Pharmaceutical Microbiology. $7^{\text {th }}$ Edition. Blackwell Publishing, UK. pp 472-481. http://dx.doi.org/10.1002/9780470988329 
Devlieghere F, Vermeiren L., Jacobs M, Debevere J. 2000. The effectiveness of hexamethlenetetramine incorporated plastic for the active packaging of foods. Packaging Technol Sci., 13: 117-121. http://dx.doi.org/10.1002/10991522(200005)13:3<117::AID-PTS500>3.0.CO;2-B

Espinel-Ingroff A, Fothergill A., Peter J, Rinaldi MG, Walsh, T.J. 2002. Testing conditions for determination of minimum fungicidal concentrations of new and established antifungal agents for Aspergillus spp: NCCLS Collaborative study. Journal of Clinical Microbiology 40((9): 3204-3208.

Hall CV. 2004. Watermelons as food in the 22nd century. In: Food Security and Vegitables. A global perspective. Nath, P., Gaddagimath,P.B., and Dutta, O.P. (Eds). Dr. PremNath Agricultural Science Foundation,India. Pp135-148.

Ikram M, Inamul H.1984. Screening of medicinal plants for antimicrobial activity. Fitoterapia 55, 62-64.

Irobi ON, Daranola SO. 1994. Bacteriocidal properties of crude extracts of Racar puvillosus. J.Ethnopharmacol. 42 , 3943. http://dx.doi.org/10.1016/0378-8741(94)90021-3

Jigna P, Sumitra C. 2006. In-vitro antimicrobial activities of extracts of Vitis vinifera and Cyperus rotundus. African Journal of Biomedical Research 9 (2), 89-93.

Marzouk B, Marzouk Z, Edziri H, Haloui E, Fenina N, Aouni M. 2009. Antibacterial and anticandida screening of Tunisian Citrullus colocynthis Schrad. Medenine. J Ethnopharmacol 125, 344-349. http://dx.doi.org/10.1016/j.jep.2009.04.025

Nair R, Chanda SV. 2007. Antibacterial activities of some medicinal plants of Western region on India. Trk J Bio 31, 231236.

Odugbemi TO. 2006. Outlines and pictures of medicinal plants from Nigeria, University of Lagos press, Lagos, Nigeria. p 91.

Omogbai BA. 2012. Shelf-life extension studies of tropical fruit juices with crab (Callinectes sapidus) Chitosan. Ph.D Thesis, University of Benin, Benin City, Nigeria. 391 pp.

Omogbai BA, Eze FA. 2011. Phytochemical screening and susceptibility of bacterial pathogens to extracts of Evolvulus alsinoides. Science World Journal 6 (1), 5-8. http://dx.doi.org/10.4314/swj.v6i1.70307

Romero CD, Chopin SF, Buck G, Martinez E, Garcia M, Bixby L. 2005. Antibacterial properties of common herbal remedies of the southwest. J. Ethnopharmacol 99, 253-257. http://dx.doi.org/10.1016/j.jep.2005.02.028

Shariff ZU.2001. Modern Herbal Therapy for Common Ailments. Nature pharmacy series Vol.1, Spectrum Books Ltd. Ibandan, Nigeria in Association with Safari Books (Export) Ltd. UK. pp 9-84. 